\title{
Important chemical and physical traits and variation in these traits in 'tombul' hazelnut cultivar at different elevations
}

\author{
By S. Zeki Bostan
}

Karadeniz Technical University, Faculty of Agriculture, Department of Horticulture, 52100-Ordu/TURKEY. E-mail: szbostan@hotmail.com

\section{RESUMEN}

Importantes rasgos químicos y físicos y variación en estos rasgos en plantaciones de avellana 'Tombul' en diferentes elevaciones.

Este estudio ha sido realizado en la avellana 'Tombul' que crece en cuatro elevaciones $(0-50 \mathrm{~m}, 100-150 \mathrm{~m}, 200-250 \mathrm{~m}$ y 300 ce en cuatro elevaciones $(0-50 \mathrm{~m}, 100-150 \mathrm{~m}, 200-250 \mathrm{~m}$ y 300 $350 \mathrm{~m}$ ) en la provincia de Persembe (Ordu/ Norte de Turquía) en los años 1999 y 2000. Dieciséis rasgos (contenido en aceite, proteína y ceniza como características químicas; peso, tamaño y grosor de cáscara, peso, tamaño y porcentaje del grano, cavidad interna, granos arrugados y granos buenos como características físicas; $\mathrm{pH}$, materia orgánica, fósforo y potasio en el suelo) han sido examinados en cada elevación. Las correlaciones entre características importantes del suelo, de la cáscara y del grano fueron examinadas. Las correlaciones fueron significativas positivamente entre tamaño de la cáscara-aceite, y aceite-proteína; negativamente entre proteína-tamaño grano, y proteína-grano arrugado; negativamente entre materia orgánica-grosor de cáscara, y materia orgánica-grano bueno; negativamente entre $\mathrm{pH}$-groa, y más or y $\mathrm{pH}$-grano bueno; positivamente ente grano sor de cáscara, y pH-grano bueno; positivamente ente grano bueno-grosor de cáscara; negativamente entre grano arrugadopeso del grano, y grano arrugado-porcentaje del grano; positivamente entre cavidad interna-peso de cáscara y negativamente entre cavidad interna-tamaño de cáscara; positivamente ente porcentaje del grano- peso del grano, y porcentaje del grano-tamaño del grano; positivamente entre tamaño del grano-peso del grano, y peso de cáscara-peso del grano. Diferencias significativas entre elevaciones han sido observadas para el grosor de cáscara, el contenido de ceniza en el grano, y pH en el suelo. Los coeficientes de variación más altos han sido observados para el fósforo, granos arrugados, potasio, cavidad interna y materia orgánica, respectivamente.

PALABRAS-CLAVE: Corylus avellana L - Grano - Química Física -- Cáscara - Suelo.

\section{SUMMARY}

Important chemical and physical traits and variation in these traits in 'Tombul' hazelnut cultivar at different elevations.

This study was conducted on 'Tombul' hazelnut growing at four elevations (0-50 m, 100-150 m, 200-250 m and 300-350 m) in Persembe (Ordu/ Northern Turkey) province in 1999 and 2000 years. Sixteen traits (oil, protein and ash contents as chemical; nut weight, nut size, shell thickness, kernel weight, kernel size, weight, nut size, shell thickness, kernel weight, kernel size, physical; $\mathrm{pH}$, organic matter, phosphorus and potassium in soil) were examined at each elevation. Interrelationships among important soil, nut and kernel characteristics were examined. There were significant correlation and interrelationships among the traits. The correlation between oil-nut size, oil- protein positively; protein-kernel size, protein- shriveled kernel negatively; organic matter- shell thickness, organic matter-good kernel negatively; $\mathrm{pH}$ - shell thickness, $\mathrm{pH}$-good kernel negatively; good kernel-shell thickness positively; shriveled kernel-kernel weight kernel-shell thic shriveled kernel-percent kernel negatively; internal cavity-nut weight positively and internal cavity-nut size negatively; percen kernel-kernel weight, percent kernel-kernel size positively; kerne size-kernel weight positively, and kernel weight-nut weigh positively were significant. Significant differences among elevations were observed for shell thickness, ash content in kernel, and $\mathrm{pH}$ value in soil. The highest coefficients of variation were observed for phosphorus, shriveled kernels, potassium internal cavity and organic matter, respectively.

KEY-WORDS: Corylus avellana L - Kernel -- Chemical -Physical -- Nut - Soil.

\section{INTRODUCTION}

The world's major hazelnut production areas are all located near large bodies of water and are characterized by mild, humid winters and cool summers, although the geographical range of the European hazelnut includes a wide range of climates, from subtropical along the Mediterranean to very cold in Scandinavia and Russia (Mehlenbacher, 1994). There are great genetic variability in Corylus avellana L., and most cultivars existing today are the result of natural selection and selection by man (Lagerstedt, 1975; Mehlenbacher, 1991).

Clonal variability in old fruit and nut cultivars is a widely recognized phenomenon and hazelnuts are no exception. Breeding goals regarding tree growth habit and adaptation to environmental factors vary in different regions, depending on local cultural practices and differing adaphic, climatic, pest, and disease problems. Traits such as adaptation to higher soil $\mathrm{pH}$, greater cold hardiness, etc. are required for specific regions. All important world cultivars were selected at some unknown, distant time directly from the wide-ranging wild species, Corylus avellana L., in Europe and Turkey (Thompson et al., 1996).

In Turkey, conventional production practices arising from a variety of factors have long been used and adoption of improved production technologies is quite limited. In modern hazelnut production, development of high yielding cultivars with desired quality, suitable for processing and meeting the 
needs of domestic and international markets is of considerable importance (Ayfer et al., 1986).

In hazelnut orchards involving a variety of cultivars and forms, the harvested crop is a heterogeneous mixture. In Turkey, hazelnuts are grown between $0 \mathrm{~m}$ and $750 \mathrm{~m}$ elevation. The zone between $0 \mathrm{~m}$ and $250 \mathrm{~m}, 250 \mathrm{~m}$ and $500 \mathrm{~m}$ and 500 $\mathrm{m}$ and $750 \mathrm{~m}$ are called coastal line, middle line and high line, respectively.

In the growing, 'ocak' (a traditional bush system) planting system have been used. In the ocak system, spacing between ocaks is 3-5 $\mathrm{m}$, and stem number per ocak is 6-12 in practice.

The 'Tombul' hazelnut cultivar has a high protein (16.79-18.03\%) and oil (65.92-67.98 \%) (Ayfer et al., 1986). In the province of Persembe (Ordu), 'Tombul' and 'Palaz' hazelnut cultivars are well adapted, and 'Tombul' is the main variety grown. 'Tombul' hazelnut orchards have a $65 \%$ area among the hazelnut cultivars in Persembe. The fruit of this variety has a round shape.

There is a great potential for genetic improvement by means of selection in the region. The purpose of this study was to determine the interrelationships among soil, nut and kernel traits, and variation associated with elevation for the soil, nut and kernel characteristics in 'Tombul' hazelnut cultivar grown in Persembe (Ordu) province.

The use of path analysis provides a plausible explanation of observed correlation by modeling the cause-and effect relations between the variables. Thus, it is possible to analyze the correlation coefficient of variables in the form of variance and covariance using path analysis.

\section{MATERIALS AND METHODS}

This research was conducted on 'Tombul' hazelnut grown at orchards with 50 ages and four elevations $(0-50 \mathrm{~m}, 100-150 \mathrm{~m}, 200-250 \mathrm{~m}$ and $300-350 \mathrm{~m}$ ) in Persembe (Ordu/Northern Turkey) that its area is $224 \mathrm{~km}^{2}$ province in 1999 and 2000 years.

Sixteen traits were observed: Oil $(\mathrm{O}, \%)$, protein (PR, \%), ash content (A, \%) in kernel; nut weight (NW, g), nut size (NS, cm) ((nut width + nut length +nut thickness)/3), shell thickness (ST, mm), kernel weight $(\mathrm{KW}, \mathrm{g})$, kernel size (KS, $\mathrm{cm})$ ((kernel width +kernel length +kernel thickness)/3), percent kernel, (RK, \%), internal cavity (IC, mm), shriveled kernels (SK, \%), good kernels (GK, \%); pH, organic matter $(\mathrm{OM}, \%)$, phosphorus (P, ppm), potassium (K, ppm) in soil.

Chemical analysis were determined as follows:

Ash content: $1 \mathrm{~g}$ sample was weighed in porcelain cups and was burned at $550 \pm 2{ }^{\circ} \mathrm{C}$ until white color comes into existence. The results were given as percent (Anonymous, 1988).
Protein content: Protein content was determined according to kjheldahl method by utilizing total nitrogen amount (Kacar, 1984).

Oil content: This was determined as percent by soxhalet apparatus (warm extraction) using diethyl ether solvent (Kadaster, 1960).

$\mathrm{pH}: \mathrm{pH}$ in $1: 1(\mathrm{w} / \mathrm{v})$ soil water suspension by pH-meter (Jackson, 1962).

Organic matter: Soil organic matter content was measured by Walkley Black method (Jackson, 1962).

Potasssium (K): Soil available $\mathrm{K}$ content was determined using Flame Photometry (Rowell, 1994).

Phosphorus (P): Soil available $\mathrm{P}$ content was determined as Spectrophotometric according to Olsen (Rowell, 1994).

Three orchards were selected at each elevation. These orchards were similar with respect to technical and cultural practices, and slope. These orchards had been planted by materials that had been propagated by suckers. In the orchards, ocak number was changed between $50-60 / 1000 \mathrm{~m}^{2}$. Nut samples were harvested 1 and 15 August, in 1999 and 2000 years, respectively, and dried under natural conditions. Soil samples were taken 15 days ago from harvest.

The experimental design was completely randomized design with three replicates. Three ocak (a traditional bush system) were used at each replicate. Interrelationships among the traits were determined by path analysis on computer program.

\section{RESULTS AND DISCUSSION}

Significant interrelationships among traits were determined (Table I). Total 17 significant correlations were determined for sixteen traits. Nut weight-kerne weight, nut weight-internal cavity, nut size-oil content, shell thickness-good kernels, kernel weight-kernel size, kernel weight-percent kernel, kernel size-percent kernel and oil content-protein content correlation as positively, and nut size-internal cavity, shell thickness-pH, shell thickness-organic matter, kernel weight-shriveled kernel, kernel size-protein content, percent kernel-shriveled kernel, shriveled kernel-protein content, good kernel-organic matter and good kernel-pH correlation as negatively were determined significantly.

In a study that was conducted on 'Tombul' hazelnut negative correlation between nut weight and percent kernel, shell thickness and percent kernel; positive correlation between nut weight and kernel weight, nut thickness and shell thickness, shell thickness and kernel weight were observed significantly (Bostan, 1995). Our result for the nut weight and kernel weight correlation was similar to literature. But, the other correlations were not significant in this study. 
Table I

Correlation coefficients between traits in 'Tombul'

\begin{tabular}{|c|c|c|c|c|c|c|c|c|c|c|c|c|c|c|}
\hline NW & NS & ST & $\mathrm{KW}$ & KS & PK & IC & SK & GK & $\mathrm{pH}$ & $\mathrm{OM}$ & $\mathbf{P}$ & $\mathrm{K}$ & PR & 0 \\
\hline$-0,226$ & 1,000 & & & & & & & & & & & & & \\
\hline 0,242 & $-0,339$ & 1,000 & & & & & & & & & & & & \\
\hline $0,905^{* *}$ & $-0,091$ & 0,066 & 1,000 & & & & & & & & & & & \\
\hline 0,531 & $-0,222$ & $-0,023$ & $0,672^{*}$ & 1,000 & & & & & & & & & & \\
\hline 0,356 & 0,170 & $-0,231$ & $0,719^{* \star}$ & $0,600^{*}$ & 1,000 & & & & & & & & & \\
\hline $0,739^{* *}$ & $-0,579^{\star}$ & 0,241 & 0,562 & 0,308 & 0,036 & 1,000 & & & & & & & & \\
\hline$-0,418$ & $-0,206$ & 0,229 & $-0,601^{*}$ & 0,010 & $-0,652^{*}$ & $-0,260$ & 1,000 & & & & & & & \\
\hline 0,428 & $-0,274$ & $0,578^{*}$ & 0,489 & 0,468 & 0,381 & 0,314 & 0,011 & 1,000 & & & & & & \\
\hline$-0,132$ & 0,334 & $-0,845^{\star \star}$ & $-0,055$ & 0,117 & 0,080 & $-0,182$ & $-0,129$ & $-0,724^{* *}$ & 1,000 & & & & & \\
\hline$-0,203$ & 0,270 & $-0,786^{\star \star}$ & $-0,082$ & $-0,319$ & 0,137 & $-0,252$ & $-0,432$ & $-0,580^{*}$ & 0,562 & 1,000 & & & & \\
\hline$-0,197$ & $-0,464$ & 0,226 & $-0,230$ & 0,207 & $-0,191$ & 0,025 & 0,508 & 0,312 & $-0,330$ & $-0,178$ & 1,000 & & & \\
\hline 0,048 & $-0,309$ & $-0,265$ & $-0,040$ & $-0,143$ & $-0,183$ & 0,101 & $-0,062$ & $-0,153$ & 0,164 & 0,573 & 0,429 & 1,000 & & \\
\hline$-0,148$ & 0,267 & $-0,197$ & $-0,102$ & $-0,667^{\star}$ & 0,029 & $-0,017$ & $-0,605^{*}$ & $-0,142$ & $-0,052$ & 0,545 & $-0,238$ & 0,349 & 1,000 & \\
\hline$-0,130$ & $0,658^{*}$ & 0,034 & $-0,019$ & $-0,402$ & 0,185 & $-0,245$ & $-0,451$ & 0,103 & $-0,155$ & 0,189 & $-0,126$ & $-0,005$ & $0,728^{\star *}$ & 1,000 \\
\hline 0,408 & 0,335 & $-0,020$ & 0,411 & 0,185 & 0,234 & $-0,078$ & $-0,257$ & $-0,250$ & 0,198 & 0,051 & $-0,548$ & $-0,352$ & $-0,320$ & $-0,165$ \\
\hline
\end{tabular}

${ }^{*},{ }^{* *}$ : Significant at 0.05 and 0.01 probability level, respectively

Table II

The path coefficient analysis of direct effects (DE) and indirect effects of important traits on oil content

\begin{tabular}{llllllllllllllll}
\hline & DE & & \multicolumn{10}{c}{ INDIRECT EFFECTS } \\
\hline \multirow{2}{*}{ NS } & & NW & ST & KW & KS & PK & IC & SK & GK & pH & OM & P & K & PR & A \\
& 0,75 & $-0,05$ & $-0,36$ & $-0,25$ & $-0,20$ & 0,05 & 0,48 & $-0,37$ & 0,83 & $-0,44$ & 0,13 & 0,05 & 0,21 & 0,43 & $-0,59$ \\
\hline \multirow{2}{*}{ PR } & & NW & NS & ST & KW & KS & PK & IC & SK & GK & pH & OM & P & K & A \\
& 1,62 & $-0,04$ & 0,20 & $-0,21$ & $-0,28$ & $-0,61$ & 0,01 & 0,01 & $-1,09$ & 0,43 & 0,07 & 0,26 & 0,02 & $-0,24$ & 0,56 \\
\hline
\end{tabular}

Table III

The path coefficient analysis of direct effects (DE) and indirect effects of important traits on nut weight

\begin{tabular}{llllllllllllllll}
\hline & DE & & \multicolumn{10}{c}{ INDIRECT EFFECTS } \\
\hline \multirow{2}{*}{ KW } & & NS & ST & KS & PK & IC & SK & GK & PH & OM & P & K & PR & O & A \\
& 4,93 & 0,02 & $-0,02$ & 1,73 & $-2,71$ & $-1,29$ & 0,46 & $-1,43$ & 0,14 & $-0,07$ & 0,06 & 0,05 & $-0,03$ & 0,00 & $-0,94$ \\
\hline \multirow{2}{*}{ IC } & & NS & ST & KW & KS & PK & SK & GK & pH & OM & P & K & PR & 0 & A \\
& $-2,29$ & 0,14 & $-0,09$ & 2,77 & 0,79 & $-0,14$ & 0,20 & $-0,92$ & 0,47 & $-0,21$ & $-0,01$ & $-0,14$ & $-0,01$ & $-0,02$ & 0,18 \\
\hline
\end{tabular}

The path coefficient analysis of direct and indirect effects of important traits on oil content, nut weight, shell thickness, kernel weight, percent kernel and good kernel were presented in Table II, III, IV, V, VI and VII, respectively.

The indirect effect of good kernel on oil content was more than the direct effect, and the direct of protein content on oil content was more than the indirect effects (Table II).
The direct effect of kernel weight on nut weight was more than the indirect effects, and the indirect of kernel weight due to internal cavity on nut weight was more than the indirect effects (Table III).

The direct effect of good kernel on shell thickness was more than the indirect effects; the indirect of good kernel due to $\mathrm{pH}$ on shell thickness, and the indirect effects of good kernel and $\mathrm{pH}$ due to organic 
Table IV

The path coefficient analysis of direct effects (DE) and indirect effects of important traits on shell thickness

\begin{tabular}{|c|c|c|c|c|c|c|c|c|c|c|c|c|c|c|c|}
\hline \multicolumn{3}{|c|}{$\mathrm{DE}$} & \multicolumn{13}{|c|}{ INDIRECT EFFECTS } \\
\hline \multirow{2}{*}{ GK } & & NW & NS & KW & KS & PK & IC & SK & $\mathrm{pH}$ & OM & $\mathbf{P}$ & $\mathrm{K}$ & PR & 0 & $A$ \\
\hline & 14,43 & $-0,71$ & 0,62 & $-6,81$ & $-1,76$ & 1,23 & 1,87 & $-0,03$ & $-7,00$ & 1,34 & 0,40 & $-0,46$ & $-0,01$ & 0,17 & $-2,69$ \\
\hline \multirow{2}{*}{$\mathrm{pH}$} & & NW & NS & KW & KS & PK & IC & SK & GK & OM & $P$ & $\mathrm{~K}$ & PR & 0 & A \\
\hline & 9,67 & 0,22 & $-0,75$ & 0,77 & $-0,44$ & 0,26 & $-1,08$ & 0,32 & $-10,45$ & $-1,30$ & $-0,43$ & 0,50 & $-0,01$ & $-0,25$ & 2,13 \\
\hline \multirow{2}{*}{ OM } & & NW & NS & KW & KS & PK & IC & SK & GK & $\mathrm{pH}$ & $\mathbf{P}$ & $\mathrm{K}$ & PR & 0 & A \\
\hline & $-2,32$ & 0,34 & $-0,61$ & 1,14 & 1,20 & 0,44 & $-1,50$ & 1,06 & $-8,37$ & 5,43 & $-0,23$ & 1,73 & 0,05 & 0,31 & 0,55 \\
\hline
\end{tabular}

Table V

The path coefficient analysis of direct effects (DE) and indirect effects of important traits on kernel weight

\begin{tabular}{|c|c|c|c|c|c|c|c|c|c|c|c|c|c|c|c|}
\hline \multicolumn{3}{|c|}{$\mathrm{DE}$} & \multicolumn{13}{|c|}{ INDIRECT EFFECTS } \\
\hline \multirow{2}{*}{ NW } & & NS & ST & KS & PK & IC & SK & GK & $\mathrm{pH}$ & $\mathrm{OM}$ & $\mathbf{P}$ & K & PR & 0 & A \\
\hline & 0,34 & 0,03 & $-0,05$ & $-0,21$ & 0,06 & 0,10 & 0,17 & 0,35 & $-0,07$ & 0,03 & $-0,04$ & 0,00 & 0,03 & $-0,01$ & 0,18 \\
\hline \multirow{2}{*}{ KS } & & NW & NS & ST & PK & IC & SK & GK & $\mathrm{pH}$ & OM & $\mathbf{P}$ & $\mathrm{K}$ & PR & 0 & A \\
\hline & $-0,39$ & 0,18 & 0,03 & 0,01 & 0,09 & 0,04 & 0,00 & 0,38 & 0,06 & 0,05 & 0,04 & $-0,01$ & 0,15 & $-0,03$ & 0,08 \\
\hline \multirow{2}{*}{ PK } & & NW & NS & ST & KS & IC & SK & GK & $\mathrm{pH}$ & $\mathrm{OM}$ & $\mathbf{P}$ & K & PR & 0 & A \\
\hline & 0,16 & 0,12 & $-0,02$ & 0,05 & $-0,24$ & 0,01 & 0,26 & 0,31 & 0,04 & $-0,02$ & $-0,04$ & $-0,01$ & $-0,01$ & 0,01 & 0,10 \\
\hline \multirow{2}{*}{ SK } & & NW & NS & ST & KS & PK & IC & GK & $\mathrm{pH}$ & OM & $P$ & $\mathrm{~K}$ & PR & 0 & A \\
\hline & $-0,40$ & $-0,14$ & 0,03 & $-0,05$ & 0,00 & $-0,10$ & $-0,04$ & 0,01 & $-0,06$ & 0,07 & 0,10 & 0,00 & 0,13 & $-0,03$ & $-0,11$ \\
\hline
\end{tabular}

Table VI

The path coefficient analysis of direct effects (DE) and indirect effects of important traits on percent kernel

\begin{tabular}{|c|c|c|c|c|c|c|c|c|c|c|c|c|c|c|c|}
\hline \multicolumn{3}{|c|}{$\mathrm{DE}$} & \multicolumn{13}{|c|}{ INDIRECT EFFECTS } \\
\hline \multirow{2}{*}{ KW } & & NW & NS & ST & KS & IC & SK & GK & $\mathrm{pH}$ & $\mathrm{OM}$ & $\mathbf{P}$ & $\mathrm{K}$ & PR & 0 & A \\
\hline & 2,21 & $-3,29$ & 0,02 & 0,05 & 0,65 & 0,61 & $-0,58$ & 0,53 & $-0,06$ & 0,00 & 0,07 & $-0,02$ & $-0,17$ & 0,00 & 0,68 \\
\hline \multirow{2}{*}{ KS } & & NW & NS & ST & KW & IC & SK & GK & $\mathrm{pH}$ & OM & $P$ & $\mathrm{~K}$ & PR & 0 & A \\
\hline & 0,92 & $-1,93$ & 0,06 & $-0,02$ & 1,49 & 0,33 & 0,01 & 0,50 & 0,12 & 0,01 & $-0,07$ & $-0,06$ & $-1,09$ & $-0,04$ & 0,31 \\
\hline \multirow{2}{*}{ SK } & & NW & NS & ST & KW & KS & IC & GK & $\mathrm{pH}$ & $\mathrm{OM}$ & $\mathbf{P}$ & $\mathrm{K}$ & PR & 0 & A \\
\hline & 0,97 & 1,52 & 0,05 & 0,16 & $-1,33$ & 0,01 & $-0,28$ & 0,01 & $-0,13$ & 0,02 & $-0,16$ & $-0,03$ & $-0,99$ & $-0,04$ & $-0,43$ \\
\hline
\end{tabular}

matter on shell thickness were more than the direct effect (Table IV).

The indirect effect of good kernel due to nut weight, the direct effect of kernel size, the indirect effect of good kernel due to percent kernel and the direct effect of shriveled kernel on the kernel weight were more than others (Table V).

The indirect effects of nut weight due to kernel weight, kernel size and shriveled kernel on percent kernel were more than theirs direct effects (Table VI).

The indirect effects of $\mathrm{pH}$ due to shell thickness and organic matter, and the direct effect of $\mathrm{pH}$ on good kernel were more than others (Table VII).
Cultivar properties, as well as agroecological conditions, influenced the chemical content of kernel and nut traits in hazelnut (Miletic et al., 1997). In our study, significant differences among elevations were observed for shell thickness; ash content and $\mathrm{pH}$ value (Table VIII). The other traits were not significant to elevations. In a study, it was carried out to determine the effects of geographical region and climate on hazelnut production and varietal performance; the climate and soil characteristics and mean yields ( $\mathrm{g} / \mathrm{tree}$ ) were differed according to elevations and distances from coast (Baldwin et al., 2001). In the other study, it was determined that 
Table VII

The path coefficient analysis of direct effects (DE) and indirect effects of important traits on good kernel

\begin{tabular}{|c|c|c|c|c|c|c|c|c|c|c|c|c|c|c|c|}
\hline \multirow{2}{*}{\multicolumn{2}{|c|}{$\mathrm{DE}$}} & \multicolumn{14}{|c|}{ INDIRECT EFFECTS } \\
\hline & & NW & NS & KW & KS & PK & IC & SK & $\mathrm{pH}$ & OM & $P$ & $\mathrm{~K}$ & PR & 0 & A \\
\hline ST & 0,27 & $-0,06$ & $-0,07$ & 0,07 & $-0,01$ & $-0,02$ & $-0,02$ & 0,12 & 0,50 & $-0,12$ & $-0,07$ & 0,00 & $-0,03$ & 0,00 & 0,01 \\
\hline \multirow{2}{*}{$\mathrm{pH}$} & & NW & NS & ST & KW & KS & PK & IC & SK & OM & $\mathbf{P}$ & $\mathrm{K}$ & PR & 0 & $A$ \\
\hline & $-0,59$ & 0,03 & 0,07 & $-0,23$ & $-0,05$ & 0,03 & 0,01 & 0,01 & $-0,07$ & 0,09 & 0,08 & 0,00 & $-0,01$ & 0,01 & $-0,11$ \\
\hline \multirow{2}{*}{ OM } & & NW & NS & ST & KW & KS & PK & IC & SK & $\mathrm{pH}$ & $\mathbf{P}$ & $\mathrm{K}$ & PR & 0 & $A$ \\
\hline & 0,15 & 0,05 & 0,06 & $-0,22$ & $-0,08$ & $-0,09$ & 0,01 & 0,02 & $-0,23$ & $-0,33$ & 0,04 & 0,01 & 0,07 & $-0,02$ & $-0,03$ \\
\hline
\end{tabular}

Table VIII

Average values for 16 traits at four elevations in 'Tombul' hazelnut

\begin{tabular}{|c|c|c|c|c|}
\hline \multirow{2}{*}{ Traits } & \multicolumn{4}{|c|}{ Elevation (m) } \\
\hline & $0-50$ & $100-150$ & $200-250$ & $300-350$ \\
\hline NW (g) & 1,797 & 1,877 & 1,757 & 1,743 \\
\hline NS (cm) & 1,670 & 1,643 & 1,643 & 1,663 \\
\hline $\mathrm{ST}^{1}(\mathrm{~mm})$ & $0,870 \mathrm{~B}$ & $1,040 \mathrm{~A}$ & $0,950 \mathrm{AB}$ & $0,980 \mathrm{AB}$ \\
\hline $\mathrm{KW}(\mathrm{g})$ & 1,000 & 1,027 & 0,953 & 0,980 \\
\hline $\mathrm{KS}(\mathrm{cm})$ & 1,277 & 1,260 & 1,290 & 1,263 \\
\hline PK (\%) & 55,617 & 54,700 & 54,220 & 56,200 \\
\hline $\mathrm{IC}(\mathrm{mm})$ & 0,990 & 1,467 & 1,080 & 0,937 \\
\hline SK $(\%)$ & 6,667 & 7,000 & 16,333 & 6,333 \\
\hline GK (\%) & 66,000 & 92,667 & 84,333 & 92,000 \\
\hline $\mathrm{pH}^{2}$ & $6,343 \mathrm{~A}$ & $4,817 \mathrm{~B}$ & $5,737 \mathrm{AB}$ & $5,050 \mathrm{~B}$ \\
\hline OM (\%) & 2,735 & 2,120 & 2,087 & 2,233 \\
\hline$P(p p m)$ & 23,737 & 50,280 & 92,267 & 69,710 \\
\hline K (ppm) & 425,000 & 559,667 & 569,000 & 354,333 \\
\hline PR (\%) & 17,230 & 17,467 & 16,960 & 17,617 \\
\hline $\mathrm{O}(\%)$ & 59,950 & 60,057 & 59,697 & 60,533 \\
\hline$A^{3}(\%)$ & $2,697 \mathrm{~A}$ & $2,467 \mathrm{AB}$ & $2,170 \mathrm{~B}$ & $2,247 \mathrm{~B}$ \\
\hline
\end{tabular}

$1 \operatorname{LSD}(0.05): 0,113$

2LSD $(0.01): 1,400$

${ }^{3} \operatorname{LSD}(0.05): 0,301$

'Negret' cultivar presented high variations of its characteristics between years and zones of production, and in some areas 'Negret' trees produced nuts with very good chemical characteristics, while in orchards with bad management or with bad environmental conditions nuts produced are of poor quality (Romero et al., 1997). Results of our study are similar to other studies results for some nut, kernel and soil characteristics.

The highest values for these traits were observed at $100-150 \mathrm{~m}, 0-50 \mathrm{~m}$ and $0-50 \mathrm{~m}$, and the lowest at 0-5- $\mathrm{m}, 200-250 \mathrm{~m}$ and 100-150 m, respectively. In other studies that were conducted on 'Tombul' hazelnut, positive significant correlation between shell cracking resistance and shell thickness were determined (Cetiner, 1976; Bostan, 1999), and it was determined that the shell cracking resistance was significantly affected by the elevations (Bostan, 1999). According to these studies, shell thickness was significantly affected by the elevations. Thus, our results for shell thickness were nearly identical to those in previous studies.

The minimum, maximum and mean values and coefficients of variation were presented in Table IX.

The highest coefficients of variation were 71.00 $\%, 64.10 \%, 51.84 \%, 32.88 \%$ and $21.56 \%$ for phosphorus, shriveled kernel, potassium, internal cavity and organic matter, respectively.

In previous studies that were carried out in Ordu and Giresun provinces, the coefficient of variation for nut weight, kernel weight and kernel percentage were $10.05 \%, 8.10 \%$ and $5.73 \%$ in 'Tombul' (Bostan et al., 1997), for nut weight, shell thickness, kernel weight, internal cavity and percent kernel were $8.62 \%, 13.07$ 
Table IX

Minimum, maximum and mean values, and coefficients of variation for $\mathbf{1 6}$ traits

\begin{tabular}{lllll}
\hline & Min. & Max. & Mean & CV \\
\hline NW (g) & 1,69 & 1,89 & 1,79 & 4,30 \\
NS (cm) & 1,62 & 1,69 & 1,66 & 1,17 \\
ST (mm) & 0,83 & 1,14 & 0,96 & 8,53 \\
KW (g) & 0,90 & 1,07 & 0,99 & 5,75 \\
KS (cm) & 1,20 & 1,35 & 1,27 & 3,42 \\
PK (\%) & 53,23 & 57,63 & 55,18 & 2,61 \\
IC (mm) & 0,33 & 1,67 & 1,12 & 32,88 \\
SK (\%) & 2,00 & 21,00 & 9,08 & 64,10 \\
GK (\%) & 42,00 & 97,00 & 83,75 & 18,56 \\
pH & 4,55 & 6,88 & 5,49 & 13,11 \\
OM (\%) & 1,36 & 3,35 & 2,29 & 21,56 \\
P (ppm) & 8,18 & 150,03 & 58,99 & 71,00 \\
K (ppm) & 163,00 & 938,00 & 477,00 & 51,85 \\
PR (\%) & 16,58 & 18,01 & 17,32 & 2,60 \\
O (\%) & 59,09 & 61,00 & 60,06 & 0,74 \\
A (\%) & 2,10 & 2,88 & 2,40 & 10,61 \\
\hline
\end{tabular}

$\%, 12.70 \%, 35.43 \%$ and $2.71 \%$ in 'Tombul' (Bostan, 2001), respectively. In our study, nut weight, shell thickness and kernel weight values are lower than literature results, and percent kernel and internal cavity values are similar to those from other studies.

\section{CONCLUSION}

There are significant correlation and interrelationships among the important soil, nut and kernel traits in 'Tombul' hazelnut cultivar. The shell thickness, ash content in kernel and $\mathrm{pH}$ value in soil is significant difference among elevations in Persembe province. It appears that for characteristics internal cavity, shriveled kernel, organic matter, phosphorus and potassium values, coefficients variation are high.

\section{REFERENCES}

Anonymous, (1988). Gida maddeleri muayene ve analiz metotlari. Tarim Orman ve Köyisleri Bak. Koruma ve kontrol Genel müd., Bursa.

Ayfer M., Uzun A., Bas F. (1986). Türk Findik Çesitleri. Karadeniz Bölgesi Findik Ihracatçilar Birligi, Ankara.

Baldwin, B., Gilchrist, K., Snare, L. (2001). Variations in flowering, growth and yield of hazelnut cultivars and grower's selections in Australia. Acta Hort., 556 , grower's

Bostan, S.Z. (1995). Tombul ve Kalinkara findik çesitlerinde önemli meyve özellikleri arasindaki iliskilerin path analizi ile belirlenmesi. BAHÇE, 24(1-2), 53-60.

Bostan S.Z., Islam A., Sen S.M. (1997). Investigation on nut development in hazelnuts and determination of nut characteristics and variation within cultivars in some hazelnut cultivars. Acta Hort. 445,101-108.

Bostan, S.Z. (1999 a). Findikta Kabuk Kirilma Direnci lle Diger Bazi Meyve Özellikleri Arasindaki lliskiler Üzerine Bir Arastirma. BAHÇE, 28 (1-2), 21-27.

Bostan, S.Z. (1999 b). Findikta Kabuk Kirilma Direncinin Rakim, Meyve Nem Içerigi ve Illere Göre Degisimi
Üzerine Bir Arastirma. Atatürk Üniv. Zir. Fak. Derg., 30(1), 11-14.

Bostan, S.Z. (2001). Variation In Morphological And Pomological Characteristics In Hazelnut At Six Elevations. Acta Hort., 556, 197-201.

Çetiner, E. (1976). Karadeniz Findik Bölgesi Özellikle Giresun ve Cevresinde Tombul Cesidi Üzerinde Seleksiyon Çalismalari ile Bunlari Tozlayici Yuvarlak Tiplerin Seçimi Üzerinde Arastirmalar. Ege Bölge Zirai Tiplerin Seçimi Uzerinde Arastirmalar. Ege
Aras.Ens.(Basilmamis Doktora Tezi), Izmir.

Jackson, M.C. (1962). Soil chemical analysis. Prentice Hall. Inc., Eng., Cliff., USA.

Kacar, B. (1984). Bitki Besleme Uygulama Klavuzu. Ankara Üniv.Ziraat Fak. Yayin No: 900, Ankara.

Kadaster, I.E. (1960). Zirai Kimya Tatbikati. I. Yem analizleri. Ankara Üniv. Ziraat Fak. Yayini. 113: 50-63.

Lagersted, H. B. (1975). Filberts. Advances in Fruit Breeding, pp. 456-489. (Editor: J. Janick and J. N. Moore).Purdue Univ. Press. West Lafayette Indiana, USA.

Mehlenbacher, S.A. (1991). Hazelnuts (Corylus). Genetic resources of temperate fruit and nut crops, $\mathrm{pp}$ : 791-836. (Edited by Moore, J.N.; Ballington, J.R.). 2. ISHS, Wageningen, The Netherlands.

Mehlenbacher, S.A. (1994). Genetic improvement of the Hazelnut. Acta Hort., 351, 23-38.

Miletic, R., Ogasanovic, D.O., Mitrovic, M., Plazinic, R. (1997). Results of investigating some hazelnut (Corylus avellana L.) cultivars in arid conditions. Acta Hort. 445, 73-78.

Romero, A., Tous, J., Plana, J., Diaz, I., Boatella, J. Garcia, J., Lopez, A., (1997). Commercial quality characterization of Spanish 'Negret' cultivar. Acta Hort., 445, 157-163.

Rowell, D.L. (1994). Soil Science Methods and Applications. Addison Werkley Longman limited. Edinburgh Gate, Harlow.

Thompson, M.M., Lagersted, H.B., Mehlenbacher, S.A. (1996). Hazelnuts. Fruit Breeding (Edited by Jules Janick and James N. Moore), Vol. III, Chapter 3, pp. 125-184. 